for the cure of blindness and cancer. A sad end for one who, though a quack and mountebank, has been ranked by historians in the illustrious company of pioneer British Ophthalmographers. There is no cause to regret the scarcity of his book. It is best buried under the dust of libraries. In the concluding word he took over from Guillemeau's book: Farewel!

\title{
REFERENCES
}

Hirschberg, J.-In Graefe-Saemisch, 2te. Aufl., Bd. 14, Abth. 1, S. 122, Leipzig, 1911.

Shastid, I. H.-Amer. Encyclop. Ophthal., Vol. IX, p. 8,782, Cleveland, 1917.

James, R. R.-Trans. Ophthal. Soc. U.K., Vol XLI, p. 342, 1921.

\section{A LATE SIXTEENTH CENTURY OPHTHALMIC BOOK IN ENGLISH}

\author{
BY \\ ARNOLD SORSBY
}

LON DON

"A treatise of one hundred and thirteene diseases of the Eyes and. Eye-Liddes," London, 1622, (Fig. 1) is generally regarded as the earliest separate and complete work on eye diseases in English, a view thus expressed by Casey $\mathrm{A}$. Wood ${ }^{1}$ in 1902 , and repeated by him in a qualified form in the American Encyclopedia of Ophthalmology. Even Hirschberg ${ }^{2}$ mistakenly assumes that the first English book on Ophthalmology was Banister's, a view expressed in the first volume of his Geschichte but retracted in the second, where he points out that Banister's book consists largely of an unacknowledged translation from Jacques Guillemeau's Des Maladies de l'Oeil qui sont en Nombre de Cent Treize aux quelles il est Subject" (Paris, 1585). Actually the book passing under Banister's name is a collection of five separate treatises, running to 478 unnumbered pages, of which the first part only, named "Banister's Breviary of the Eyes," running to 112 pages, is his. The bulk of the volume, from p. 113 to p. 367, is taken up by the unacknowledged translation of Guillemeau's book, introduced by a separate title page (Fig. 2). The third section, running to 30 pages, is an unacknowledged reprint of Walter Bailey's " $A$ briefe Treatise concerning the preseruation of the Eye-sight." Рp. 399477 are taken up by an introduction of two pages and by a 41-page "Discourse of the Scorby" and a 34-page essay on "The nature and divers kinds of Cancers or Cankers," the first essay being 
translated out of "Wyers observations" and the second "was painfully weaved by Textor."

That this particular edition, copies of which are easily come across, is not the first ophthalmic book in English, is obvious enough from the title page-shown in Fig. 1-which indicates that The Treatise, etc. is "the second time published." Moreover, Richard Banister, in a lengthy dedication To the Reader, draws

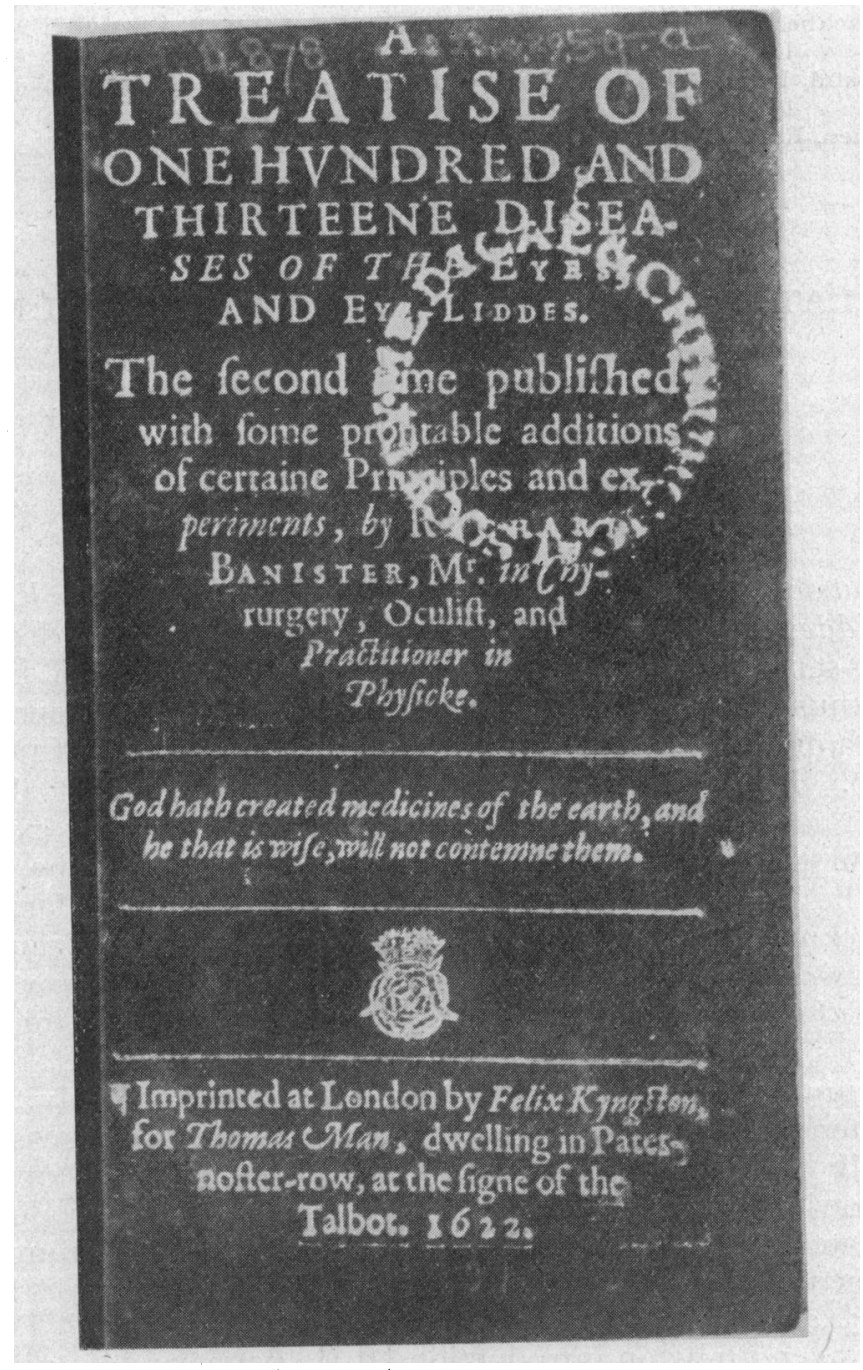

FIG. 1.

Title page of Banister's Treatise of the Eyes (so called). 


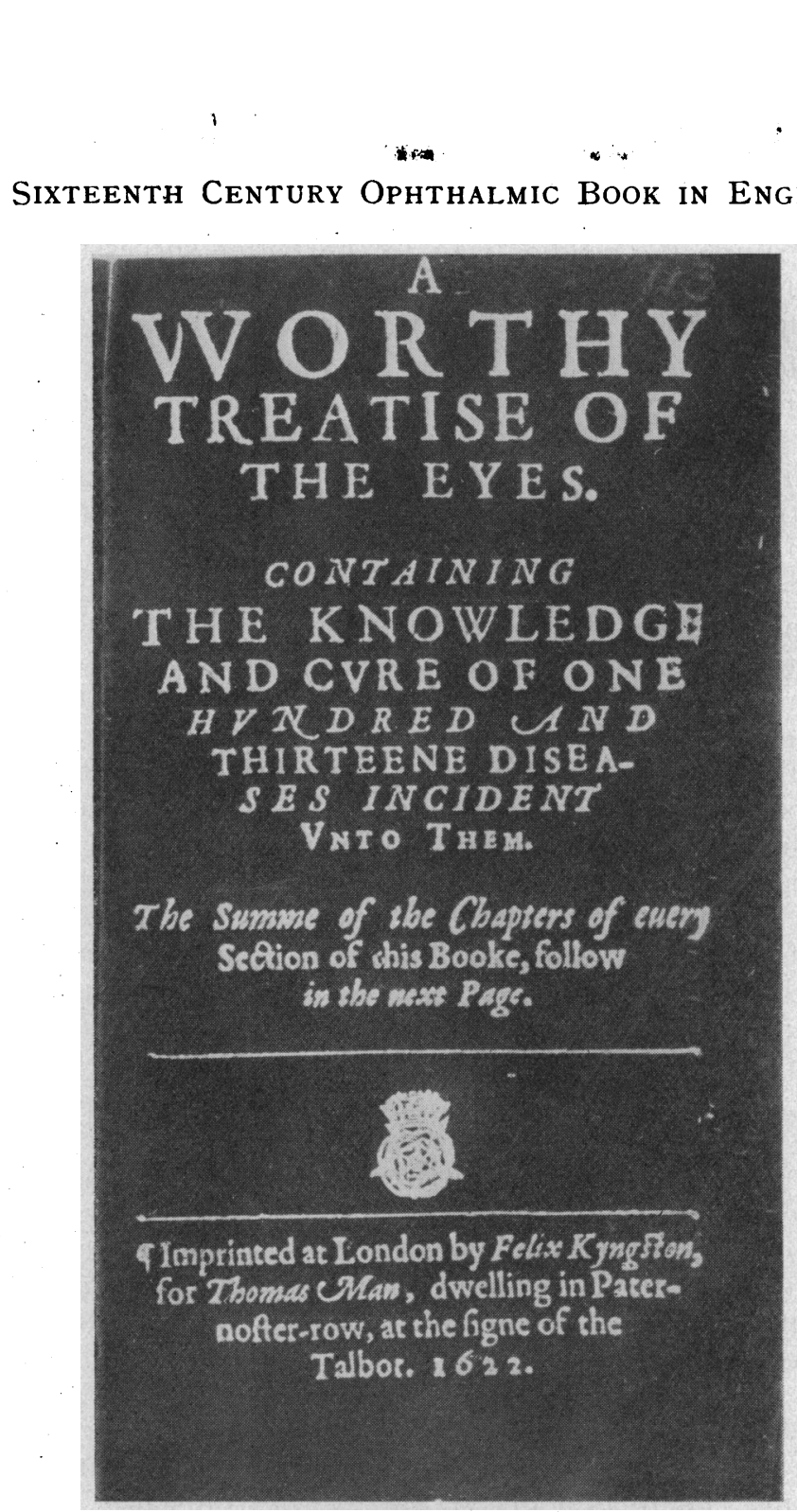

FIG. 2 .

Subsidiary title page following Banister's Breviary in A treatise of one hundred and thirteene diseases, etc.

attention to the fact that he has "here published the labours of a worthy writer ... . who describeth an hundred and thirteene severall diseases happening to the eyes and eielids, with their particular causes, symptomes, signes and cures; the worke was dedicated to my forenamed kinsman, and being long since out of print, it is not now to be bought for money ; and this booke have I sent abroade againe, that those which delight to labour in this 
Art, may runne the readier way to the better successe. I have also added something of mine owne, that through my experience they may finde at first, what I was learning long."

It is unfortunate that Banister or his publisher did not indicate more clearly the composite nature of the book passing under Banister's name, for Banister quite obviously did not intend to claim credit for the part of the book not his, as Hirschberg implies in connection with the Guillemeau treatise, and Casey Wood in connection, with the Bailey reprint.

This is seen all the more clearly from two further references Banister makes to the book in the Breviary. In the section headed "The mistaking of the use of some medicines, spoyles many an Eye; as thus" he refers the Gentle Reader to "find in the treatise of the Eyes, dedicated to my kinsman, a learned description of the severall diseases of the Eyes ... I will save a labour for adding an Antidotary to his treatise." In the last section but one he excuses himself for not dealing at greater length with cataract: "I need not; for that is sufficiently and learnedly handled in my kinsman's former treatise of the Eyes (and Doctor Barrowes Method of Physicke)* translated into English : to which bookes I referre the Reader for his better instruction." The position is made clearer still by an examination of the first edition of the translation of Guillemeau's book, the existence of which, though definitely indicated by Banister, both on the title page and the quotations from the dedication text, does nevertheless seem to have escaped the notice of both Hirschberg and Casey Wood.

The title page of the first edition (Fig. 3) clearly shows that the "One hundred and thirteene diseases" is a translation from Guillemeau. Furthermore, the composite nature of the book passing under Banister's name is already apparent in his first edition, which consists of all the parts of the second excepting Banister's Breviary. A comparison of the texts of the two editions shows the second to be a re-issue, the only changes apart from reset type, being minor alterations in spelling. Certain other points are also brought out. There is a dedication by the translator, "A.H.;" the authorship of the essay on Preservation of the Eye-sight is given and the identity of Textor, the author of the essay on Cancer, is indicated on the title page as being the translator, A.H. Furthermore, the strange juxtaposition of two works on the eye with essays on scurvy and cancer finds some explanation in the dedication of this first edition.

This dedication by the translator is addressed to his "loving

\footnotetext{
* No brackets in the original. This phrase is obviously wrongly placed, for the qualification "translated into English" could not apply to Phillip Barrough's Methode of Physicke, an English work that ran into many editions. [1st edition, 1590 ; 9th (or later) edition, 1652]. Ophthalmologically it is of no significance.
} 
Sixteenth Century Ophthalmic Book in English 349

friend Mr. John Banester, Chirurgian," the "neare and deare kinsman" who appears in the preface of Richard Banister in 1622. A.H., the translator and author of the essay on Cancer, must have been an intimate friend of John Banister, for Banister's Compedius Chirurgerie (1585) contains a prefatory letter by A.H. again addressed to his "loving friend, Master Banester." The accident of friendship and printer's material probably dictated the

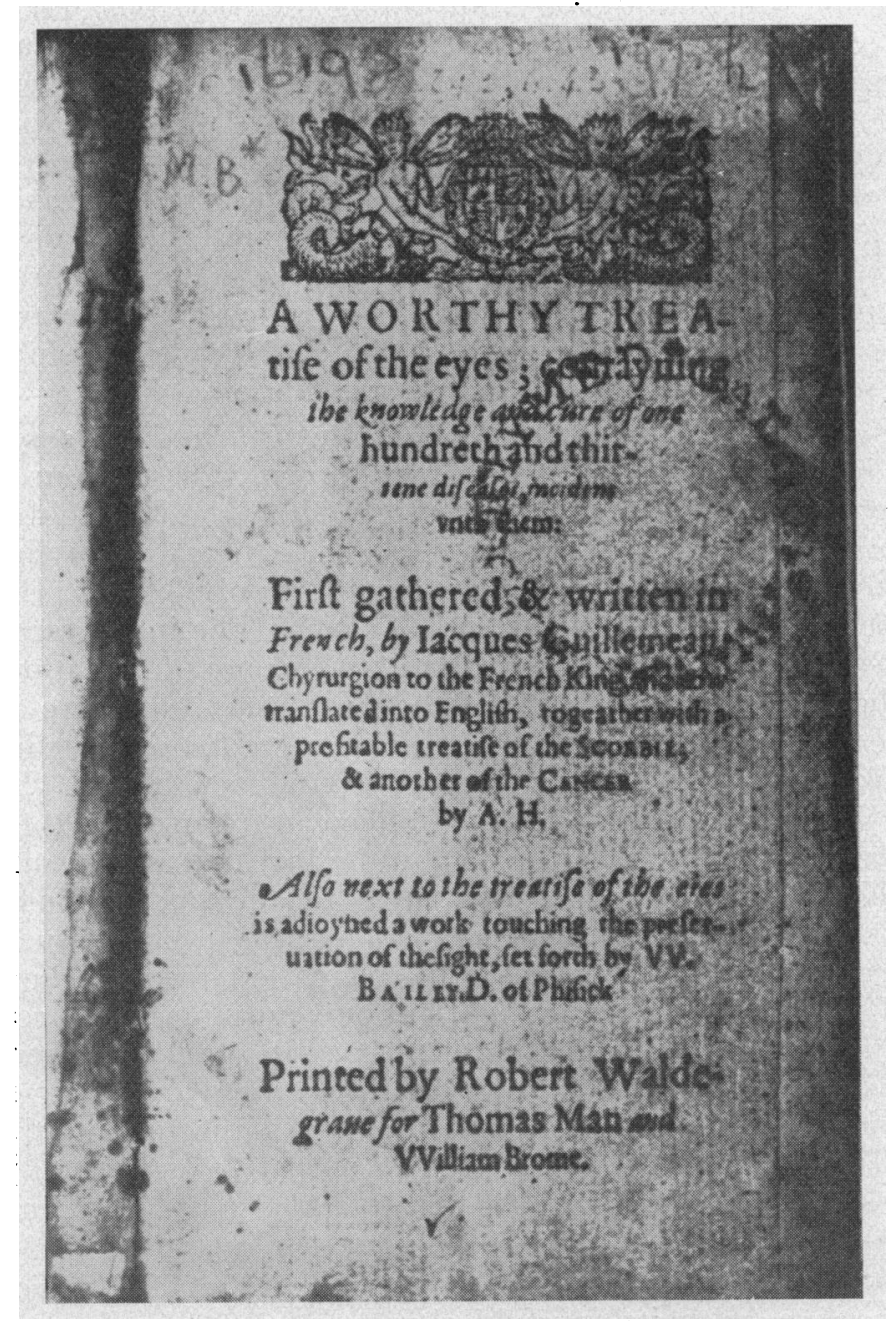

FIG. 3 .

Title page of the translation of Guillemeau's Maladies de l'Oeil. 
peculiar combination of the essays in the first edition. The essay on cancer by A. H. appears in a book which he translated, and with which he was associated sufficiently closely to be able to dedicate it to Banister; whilst the presence of the two other sections seems to be due to the printer's efforts. Apart from a certain appositeness in the presence of Bailey's essay on the Preservation of Eyesight in a book on eye diseases, there is also the fact that Bailey's discourse first appeared in 1586 , printed by the same hand-Robert Waldegrave. The essay on scurvy was included with an introductory apologv, informing the courteous and careful Chyrurgian that "this Treatise of the Scorby has beene long time prepared for thee, but it wanted a prosperous gale of winde." This remark, part of a longer introduction, is unsigned, but it is probably by the printer, notes by the printer being then a common practice. The concluding sentence lends support for this view : "The authors deserve commendacion, the interpreter deserveth friendly acceptaunce, the Printers discourage both. Farewell." The "prosperous gale of winde" for which Waldegrave was waiting may very well have been an opportunity of publishing this small essay on Scurvy together with some larger work.

Incidentally, this translation of Guillemeau and its associated essays has an interesting history of its own. Of the four copies that have been traced of this book, three show the four-fold nature described, but the fourth, though obviously the same publication, seems to be an earlier issue, and consists of only 3 parts, Bailey's essay being the missing part (Figs. $4 a, 4 b$ ). The inclusion of this essay seems to have been an afterthought, for not only is it missing from the title page and book of the first issue, but there is also positive evidence that it is definitely an interpolation, put in after the book was printed. This is shown by the fact that its 22 pages appear : nnumbered between the Guillemeau treatise and the essay on cancer, and more conclusively by the fact that it is printed on sheet K., this sheet appearing twice in the books containing Bailey's essay; the second sheet $\mathrm{K}$ is identical in both issues, and is correctly placed. The two blank pages left over in the interpolated sheet $\mathrm{K}$ seem to have been cut out, judging by the remains of the cut margin to be found in the place of the page. Furthermore, the loose bindings of the two copies at the Royal Society of Medicine allows a good examination of the connections of the title page. In the original issue it is seen as part of sheet $A$; in the latter issue it is obviously a separately added page, kept in place by a projecting edge beyond the folding of the pages.

Whatever the origin of the composite nature of this volume, its later issue, with its fourfold character, was taken over in its entirety, barring the title page and the dedication, by A. H., and re-published "with some profitable additions" by Richard Banister. 


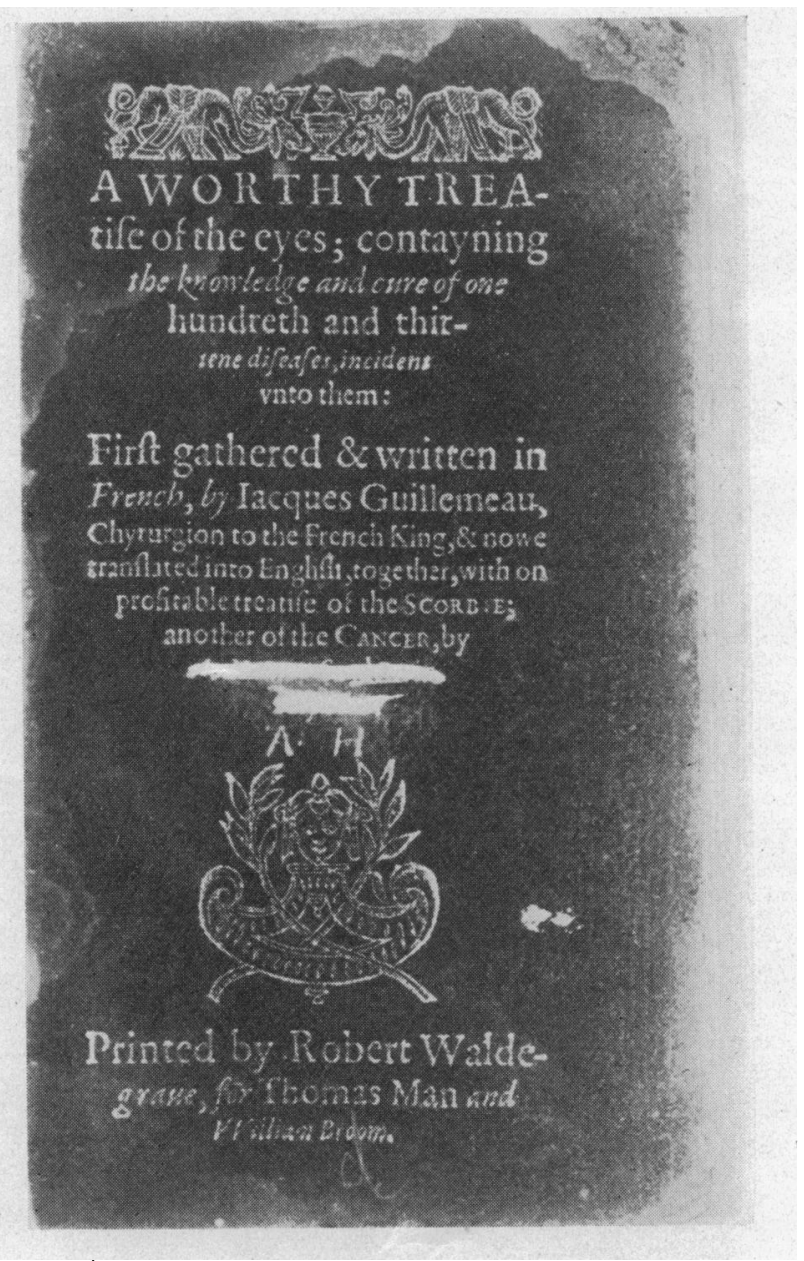

FIG. $4 a$.

Title page of an earlier issue than the one shown in Fig. 3. The name of the translator and author of the treatise on Cancer is obliterated by an ink mark and replaced by initials-A.H., the same as in the title page shown in Fig. 3 .

Whilst this definitely disposes of any claim for him as the author or even the editor of the first systematic ophthalmic book in English, it also clears him from the charge of "lifting" proferred against him by Hirschberg and Casey Wood.

It is perhaps worth adding that Banister's position in connection with the 1622 edition was fully described as long ago as 1780 by Aiken, ${ }^{3}$ who, in his sketch of Richard Banister, points out 
Guillemeau's and Bailey's responsibilities. Hutchinson, ${ }^{4}$ in 1799 , repeats Aiken's observations, which are further repeated in the Dictionary of National Biography. ${ }^{5}$ Aiken also states that the

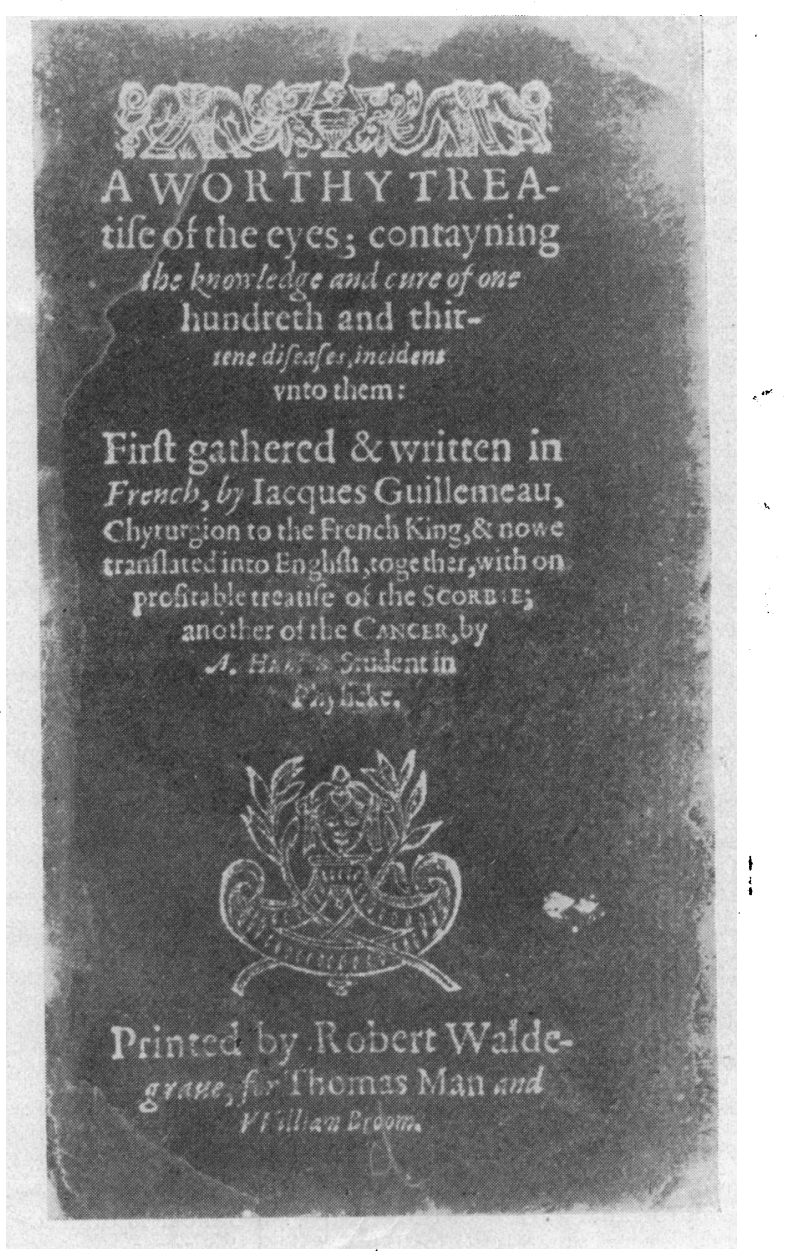

FIG. $4 b$ :

Same as $4 a$. Ink mark washed out. The book belongs to the Bowman Library (Royal Society of Medicine).

translation from Guillemeau was done by "one A. H." He must, therefore, have seen a first edition of the translation ; as, however, he does not catalogue the reprint of Bailey in this edition, amongst the various editions of Bailey's paper, it seems likely that he saw the first issue only of the translation of Guillemeau. 


\section{A worthy Treatise of the eyes; contayning the knowledge and cure of one hundreth and thirteene diseases incident unto them}

The book would appear to be distinctly rare. Aiken, in 1780 , probably knew the book; James $^{6}$ noted it in 1922 among the treasures of the Bowman Library. There is no copy at the British Museum, nor at the Royal College of Surgeons. Two copies are available at the Royal Society of Medicine, one belonging to the Society and the other in the Ophthalmological Society (Bowman Library). Another copy is to be found at the Medical Society of London. Through the Short-title Catalogue of English books, ${ }^{7}$ a fourth has been traced to the Cambridge University Library. The book is not indexed in the Catalogue of the Surgeon-General's Library.

The book is in duodecimo size. In its second issue it contains 305 pages of which 26 are devoted to the title-page and introductory matter; 190 to the text of Guillemeau's treatise; 22 to Bailey's essay; of the remaining 67 pages two pages are taken up by dedication To the Courteous and careful Chyrurgian, 36 pages by Wyers and 29 by $\mathrm{A}$. H. on Cancer. The first issue only differs in its title page and in the absence of Bailey's essay.

In the first issue, the identity of $\mathrm{A}$. $\mathrm{H}$. was disclosed on the title page, but in the only copy seen the name was blotted out with ink. Unfortunately the name does not show clearly after washing out the ink, but it seems to have been "A. Hunton." (Figs. 4a, 4b.) His dedication to Banister, who lived in Nottingham, is from "E. M. in N."-probably East Markham in Nottinghamshire. No information on A. Hunton could be traced.

Of the four copies examined, only two were perfect, one belonging to the Medical Society of London, and the other to the Ophthalmological Society (Bowman Library, Royal Society of Medicine), the first being a second issue, and the second a first issue. In the copy belonging to the Royal Society of Medicine, Sheets $A$ and $B$ are missing; the text begins on $C$ in the middle of a sentence, though the page is numbered 1 . The copy in the Cambridge University Library contains the full text of Guillemeau, but the introductory matter is missing. It begins at B.2 ; furthermore, though its title page refers to the essay by Bailey, this is not present.

In all the four copies the pages are badly numbered. The introductory matter is not numbered at all, numeration beginning after 22 pages of text, on $C$. Irregularities occur further on. Thus, p. 48 is followed by $85-90 ; 90$ bv $19 ; 92$ by $107 ; 107$ by $104-107$; 119 by $200,201,122,123,102,205,126,127,208,129$. In spite of this topsy-turvy numeration, the text is continuous. 
As shown on the title page, the book was printed by Robert Waldegrave, for Thomas Man and William Brome, who were the publishers.

\section{Date of publication:}

Unfortunately there is no indication of the year of publication of this book, and one has to rely on indirect evidence only. The earliest date of publication could not be before 1585 , the date of the appearance of Guillemeau's book in French; the latest date must be before 1622, when the book had "long since" been out of print. Robert Waldegrave printed books between 1578 and 1603, but as Thomas Man and William Brome entered into partnership in 1585 and William Brome was dead by October 4, 15918 (books being then entered under the name of Widow Brome), the date of publication is narrowed down to between 1585-91. A search through the Transcripts of Stationer's Register ${ }^{9}$ for the years in question fails to reveal any entry of the book, but the last book entered in London under Waldegrave's name is 1589, in which year he became fugitive to avoid arrest for printing Puritan literature. It is therefore likely that the book was printed between 1585 and 1589 . The book may never have been registered at Stationer's Hall, though it is just possible that it was entered on May 13th, 1588, for on that date there is an entry against Waldegrave's name: "A copie whereof he is to bring the title." Presumptive evidence that the book was published after 1585, in or after 1586, is the fact that Walter Bailey's discourse was first printed in 1586, by Waldegrave (and entered by him in Stationer's Hall). (Bailey's monograph, fully described by D'Arcy Power, ${ }^{10}$ had an extraordinary vogue; first printed in 1586 , it had a sixth edition in 1602, and subsequently appeared in combination with other works in 1616,1622,1626,1633, and by itself in 1654 and 1673. Of the intermediate four editions between 1586 and 1602 , nothing is known, and the reprint in this undated translation of Guillemeau is undoubtedly one of the missing editions, unless indeed it was published before the presumably first edition of 1586 . There is no special title page for Bailey's monograph in the Guillemeau-Bailey-Wyers-A. H. compilation. The text differs in no way from that of the other editions, apart from variations in spelling.)

I am indebted to Sir D'Arcy Power and to Mr. H. E. Powell and Mr. G. F. Home of the Library of the Royal Society of Medicine, for much help and advice in the work recorded here. 


\section{Summary}

1. The first edition of the translation into English of Jacques Guillemeau's "Maladies de l'Oeil"' is described. The translation was done by one A. H. (? A. Hunton.) Two issues seem to have appeared. Of the four copies traced three belong to the second issue and one to the first.

2. The book was published between 1585 and 1589 .

3. The second issue differs from the first in containing Walter Bailey's "Briefe Treatise concerning the Preservation of the Sight" (constituting one of the missing editions of this treatise) and in giving the initials of the translator instead of his name, on the substituted title page.

4. Both issues were composite works ; in addition to the translation by Guillemeau, they also contain an essay on Scurvy by Johan Wierus, and one on Cancer by A. H.

5. The second issue, with its four component parts, was reprinted in 1622, together with A Breviary on the Eyes written by Richard Banister in 1621. This collected work of 5 sections has mistakenly passed down as being a Treatise on the Eyes by Richard Banister. No such claim was made by Banister.

\section{REFERENCES}

1. Wood, C. A.-Jl. Am. Med. Assocn., Vol. II, p. 1152, 1902; Amer. Encycl. Ophthal., pp. 879, 5656, 8754, 8782; Bull. Soc. Med. History, Chicago, Vol. II. p. 147, 1920.

2. Hirschberg, J.-Geschichte der Augenheilkunde (Graefe-Saemisch), 2nd Edition, Vol. I, p. 20; Vol. II, p. 330.

3. Aiken, J.-Biographical Memoirs of Medicine in Great Britain. London, 1780.

4. Hutchinson, B.-Biographica Medica. London, 1799.

5. Dictionary of National Biography. Article on Richard Banister.

6. James, R. R.-The Bowman Library. Brit. Jl. of Ophthal., Vol. VI, p. 515 , 1922.

7. Pollard and Redgrave.-Short title Catalogue of English books, 1475-1640. London, 1926.

8. McKerrow, R. B. (Editor). - A Dictionary of Printers, Booksellers in England . . . of English books, 1557-1640. London, 1910.

9. Transcripts of Stationers' Registers by E. Asher. Vol. II and Vol. V.

10. Power, Sir D'Arcy.-Dr. Walter Bayley and his works. 1529-1592. Medic.Chirurg. Trans., Vol. XC, p. 415. 1907. 